\title{
Development of Financial Derivatives Market-in Indian context
}

\section{3}

\author{
Dr. HLU Bullappa \\ Assistant Professor \\ GVPP.Govt.First Grade College \\ Hagaribommanahalli-Ballari
}

\section{Abstract}

Risk is a characteristic feature of most commodity and capital markets. Variations in the prices of agricultural and non-agricultural commodities are induced, over time, by demand-supply dynamics. The last two decades have witnessed many-fold increase in the volume of international trade and business due to the wave of globalization and liberalization sweeping across the world. This has led to rapid and unpredictable variations in financial assets prices, interest rates and exchange rates, and subsequently, to exposing the corporate world to an unwieldy financial risk. In the present highly uncertain business scenario, the importance of risk management is much greater than ever before. The emergence of derivatives market is an ingenious feat of financial engineering that provides an effective and less costly solution to the problem of risk that is embedded in the price unpredictability of the underlying asset. In India, the emergence and growth of derivatives market is relatively a recent phenomenon. Since its inception in June 2000, derivatives market has exhibited exponential growth both in terms of volume and number of traded contracts. The market turnover has grown from Rs.2365 crore in 20002001 to Rs. 11010482.20 crore in 2008-2009. Within a short span of eight years, derivatives trading in India has surpassed cash segment in terms of turnover and number of traded contracts. The present study encompasses in its scope an analysis of historical roots of derivative trading, types of derivative products, regulation and policy developments, trend and growth, future prospects and challenges of derivative market in India. Some space is devoted also to a brief discussion of the status of global derivatives markets in Indain context Indian derivatives.

Keywords: Forward, Futures, Options, Financial Derivatives, Risk Management, Exchange rates

\section{Introduction}

Risk is a characteristic feature of all commodity and capital markets. Overtime, variations in the prices of agricultural and non-agricultural commodities occur as a result of interaction of demand and supply forces. The last two decades have witnessed a many-fold increase in the volume of international trade and business due to the ever growing wave of globalization and liberalization sweeping across the world. As a result, financial markets have experienced rapid variations in interest and exchange rates, stock market prices thus exposing the corporate world to a state of growing financial risk. Increased financial risk causes losses to an otherwise profitable organization. This underlines the importance of risk management to hedge against uncertainty. Derivatives provide an effective solution to the problem of risk caused by uncertainty and volatility in underlying asset. Derivatives are risk management tools that help an organization to effectively transfer risk. Derivatives are instruments which have no independent value. Their value depends upon the 
underlying asset. The underlying asset may be financial or non-financial. The present study attempts to discuss the genesis of derivatives trading by tracing its historical development, types of traded derivatives products, regulation and policy developments, trend and growth, future prospects and challenges of derivative market in India. The study is organized into four sections. Section I deals with the concept, definition, features and types of financial derivatives. Section II has been devoted to a discussion of the growth of derivatives market, and regulation and policy development. Section III discusses status of global derivatives market vis-a-vis Indian derivatives market. The last section specifies summary and concluding remarks.

\section{Section I}

\section{Concept of Derivatives}

The term 'derivatives, refers to a broad class of financial instruments which mainly include options and futures. These instruments derive their value from the price and other related variables of the underlying asset. They do not have worth of their own and derive their value from the claim they give to their owners to own some other financial assets or security. A simple example of derivative is butter, which is derivative of milk. The price of butter depends upon price of milk, which in turn depends upon the demand and supply of milk. The general definition of derivatives means to derive something from something else. Some other meanings of word derivatives are:

a) Derived function: the result of mathematical differentiation; the instantaneous change of one quantity relative to another; $\mathrm{df}(\mathrm{x}) / \mathrm{dx}$,

b) Derivative instrument: a financial instrument whose value is based on another security, (linguistics) a word that is derived from another word; "'electricity' is a derivative of 'electric'. The asset underlying a derivative may be commodity or a financial asset. Derivatives are those financial instruments that derive their value from the other assets. For example, the price of gold to be delivered after two months will depend, among so many things, on the present and expected price of this commodity.

\subsection{Definition of Financial Derivatives}

Section 2(ac) of Securities Contract Regulation Act (SCRA) 1956 defines Derivative as:

A) A security derived from a debt instrument, share, loan whether secured or unsecured, risk instrument or contract for differences or any other form of security.

B) A contract which derives its value from the prices, or index of prices, of underlying securities.

\subsection{Underlying Asset in a Derivatives Contract}

As defined above, the value of a derivative instrument depends upon the underlying asset. The underlying asset may assume many forms:

A) Commodities including grain, coffee beans, orange juice;

B) Precious metals like gold and silver;

C) Foreign exchange rates or currencies;

D) Bonds of different types, including medium to long term negotiable debt securities issued by governments, companies, etc.

E) Shares and share warrants of companies traded on recognized stock exchanges and Stock Index

F) Short term securities such as T-bills; and

G) Over- the Counter (OTC) money market products such as loans or deposits.

\subsection{Participants in Derivatives Market}

1. Hedgers:They use derivatives markets to reduce or eliminate the risk associated with price of an asset. Majority of the participants in derivatives market belongs to this category.

2. Speculators: They transact futures and options contracts to get extra leverage in betting on future movements in the price of an asset. They can increase both the potential gains and potential losses by usage of derivatives in a speculative venture. 
3. Arbitrageurs:Their behavior is guided by the desire to take advantage of a discrepancy between prices of more or less the same assets or competing assets in different markets. If, for example, they see the futuresprice of an asset getting out of line with the cash price, they will take off setting positions in the two markets to lock in a profit.

\subsection{Applications of Financial Derivatives}

Some of the applications of financial derivatives can be enumerated as follows:

1. Management of risk:This is most important function of derivatives. Risk management is not about the elimination of risk rather it is about the management of risk. Financial derivatives provide a powerful tool for limiting risks that individuals and organizations face in the ordinary conduct of their businesses. It requires a thorough understanding of the basic principles that regulate the pricing of financial derivatives. Effective use of derivatives can save cost, and it can Increase returns for the organizations.

2. Efficiency in trading: Financial derivatives allow for free trading of risk components and that leads to improving market efficiency. Traders can use a position in one or more financial derivatives as a substitute for a position in the underlying instruments. In many instances, traders find financial derivatives to be a more attractive instrument than the underlying security. This is mainly because of the greater amount of liquidity in the market offered by derivatives as well as the lower transaction costs associated with trading a financial derivative as compared to the costs of trading the underlying instrument in cash market.

3. Speculation:This is not the only use, and probably not the most important use, of financial derivatives. Financial derivatives are considered to be risky. If not used properly, these can leads to financial destruction in an organization like what happened in Barings Plc. However, these instruments act as a powerful instrument for knowledgeable traders to expose themselves to calculated and well understood risks in search of a reward, that is, profit.

4. Price discover:Another important application of derivatives is the price discovery which means revealing information about future cash market prices through the futures market. Derivatives markets provide a mechanism by which diverse and scattered opinions of future are collected into one readily discernible number which provides a consensus of knowledgeable thinking.

5. Price stabilization function:Derivative market helps to keep a stabilizing influence on spot prices by reducing the short-term fluctuations. In other words, derivative reduces both peak and depths and leads to price stabilization effect in the cash market for underlying asset.

\subsection{Classification of Derivatives}

Broadly derivatives can be classified in to two categories Commodity derivatives and financial derivatives. In case of commodity derivatives, underlying asset can be commodities like wheat, gold, silver etc., whereas in case of financial derivatives underlying assets are stocks, currencies, bonds and other interest rates bearing securities etc. Since, the scope of this case study is limited to only financial derivatives so we will confine our discussion to financial derivatives only.

\subsubsection{Forward Contract}

A forward contract is an agreement between two parties to buy or sell an asset at a specified point of time in the future. In case of a forward contract the price which is paid/ received by the parties is decided at the time of entering into contract. It is the simplest form of derivative contract mostly entered by individuals in day to day's life.

\subsubsection{Futures Contract}

Futures is a standardized forward contact to buy (long) or sell (short) the underlying asset at specified price at a specified future date through a specified exchange. Futures contracts are traded on exchanges that work as a buyer or seller for the counterparty. Exchange sets the 
standardized terms in term of Quality, quantity, Price quotation, Date and Delivery place (in case of commodity). The features of a futures contract may be specified as follows:

i These are traded on an organized exchange like IMM, LIFFE, NSE, BSE, CBOT etc.

ii These involve standardized contract terms viz. the underlying asset, the time of maturity and the manner of maturity etc.

iii These are associated with a clearing house to ensure smooth functioning of the market.

iv There are margin requirements and daily settlement to act as further safeguard.

$\checkmark$ These provide for supervision and monitoring of contract by a regulatory authority.

vi Almost ninety percent future contracts are settled via cash settlement instead of actual delivery of underlying asset. Futures contracts being traded on organized exchanges impart liquidity to the transaction. The clearinghouse, being the counter party to both sides of a transaction, provides a mechanism that guarantees the honouring of the contract and ensuring very low level of default (Hirani, 2007).

\section{Following are the important types of financial futures contract:-}

1. Stock Future or equity futures,

2. Stock Index futures,

3. Currency futures, and

4. Interest Rate bearing securities like Bonds, T- Bill Futures. To give an example of a futures contract, suppose on November 2007 Ramesh holds 1000 shares of ABC Ltd. Current (spot) price of ABC Ltd shares is Rs 115 at National Stock Exchange (NSE). Ramesh entertains the fear that the share price of ABC Ltd may fall in next two months resulting in a substantial loss to him. Ramesh decides to enter into futures market to protect his position at Rs 115 per share for delivery in January 2008. Each contract in futures market is of 100 Shares. This is an example of equity future in which Ramesh takes short position on ABC Ltd. Shares by selling 1000 shares at Rs 115 and locks into future price.

\subsubsection{Options Contract}

In case of futures contact, both parties are under obligation to perform their respective obligations out of a contract. But an options contract, as the name suggests, is in some sense, an optional contract. An option is the right, but not the obligation, to buy or sell something at a stated date at a stated price. A "call option" gives one the right to buy; a "put option" gives one the right to sell. Options are the standardized financial contract that allows the buyer (holder) of the option, i.e. the right at the cost of option premium, not the obligation, to buy (call options) or sell (put options) a specified asset at a set price on or before a specified date through exchanges.

Options contracts are of two types: call options and put options. Apart from this, options can also be classified as OTC (Over the Counter) options and exchange traded options. In case of exchange traded options contract, contracts are standardized and traded on recognized exchanges, whereas OTC options are customized contracts traded privately between the parties. A call options gives the holder (buyer/one who is long call), the right to buy specified quantity of the underlying asset at the strike price on or before expiration date. The seller (one who is short call) however, has the obligation to sell the underlying asset if the buyer of the call option decides to exercise his option to buy.

Suppose an investor buys One European call options on Infosys at the strike price of Rs. 3500at a premium of Rs. 100. Apparently, if the market price of Infosys on the day of expiry is more than Rs. 3500, the options will be exercised. In contrast, a put options gives the holder (buyer/ one who is long put), the right to sell specified quantity of the underlying asset at the strike price on or before an expiry date. The seller of the put options (one who is short put) however, has the obligation to buy the underlying 
asset at the strike price if the buyer decides to exercise his option to sell. Right to sell is called a Put Options. Suppose X has 100 shares of Bajaj Auto Limited. Current price (March) of Bajaj auto shares is Rs 700 per share. $X$ needs money to finance its requirements after two months which he will realize after selling 100 shares after two months. But he is of the fear that by next two months price of share will decline. He decides to enter into option market by buying Put Option (Right to Sell) with an expiration date in May at a strike price of Rs 685 per share and a premium of Rs 15 per shares.

\subsubsection{Swaps Contract}

A swap can be defined as a barter or exchange. It is a contract whereby parties agree to exchange obligations that each of them have under their respective underlying contracts or we can say, a swap is an agreement between two or more parties to exchange stream of cash flows over a period of time in the future. The parties that agree to the swap are known as counter parties. The two commonly used swaps are: i) Interest rate swaps which entail swapping only the interest related cash flows between the parties in the same currency, and ii) Currency swaps: These entail swapping both principal and interest between the parties, with the cash flows in one direction being in a different currency than the cash flows in the opposite direction

\section{Section II}

\section{History of Derivatives Markets in India}

Derivatives markets in India have been in existence in one form or the other for a long time. In the area of commodities, the Bombay Cotton Trade Association started futures trading way back in 1875. In 1952, the Government of India banned cash settlement and options trading. Derivatives trading shifted to informal forwards markets. In recent years, government policy has shifted in favour of an increased role of market-based pricing and less suspicious derivatives trading. The first step towards introduction of financial derivatives trading in India was the promulgation of the Securities
Laws (Amendment) Ordinance, 1995. It provided for withdrawal of prohibition on options in securities. The last decade, beginning the year 2000, saw lifting of ban on futures trading in many commodities. Around the same period, national electronic commodity exchanges were also set up.

Derivatives trading commenced in India in June 2000 after SEBI granted the final approval to this effect in May 2001 on the recommendation of L.C Guptacommittee. Securities and Exchange Board of India (SEBI) permitted the derivatives segments of two stock exchanges, NSE and BSE and their clearing house/corporation to commence trading and settlement in approved derivatives contracts. Initially, SEBI approved trading in index futures contracts based on various stock market indices such as, S\&P CNX, Nifty and Sensex. Subsequently, index-based trading was permitted in options as well as individual securities.

India's derivatives markets, both OTC and exchange-traded, have seen rapid growth over the last decade, and with relatively few sputters. The successes are visible and real-several Indian exchanges rank among the world's top exchanges in terms of number of derivatives contracts traded (though the figures are exaggerated by the small size of Indian contracts compared to the major international exchanges); and there have been no large scale derivatives disasters of the sort that have roiled the advanced economies. But problems lurk not far beneath the surface. Many underlying markets are illiquid and lack depth, simultaneously increasing the need for alternative risk-management tools and hampering the development of the corresponding derivatives markets. Anecdotal evidence suggests too that Indian exchanges may be losing volumes to overseas competitors because of regulatory burdens. The challenge in this environment is to find away to sustain the growth and deepen the market, making tools of risk-management more widely available to corporate and banks, even while avoiding speculative excesses. In this context, the recent Dodd-Frank reforms in the 
US offer a useful framework for thinking about issues. The Dodd-Frank Act has as its objectives the minimization of systemic risk from derivatives use and increasing the transparency of the OTC derivatives market. Towards these ends, the Act has mandated, among other things, that those OTC derivatives that are sure

Global OTC derivatives markets, by underlying risk

Outstanding positions at end-June of the indicated year

Graph 1

Notional amounts outstanding

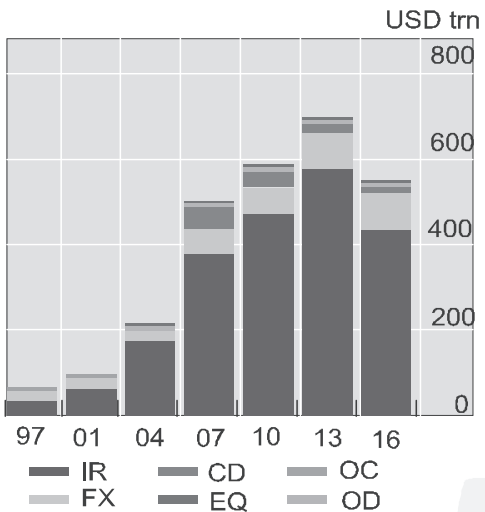

Contribution of Triennial dealers at end-June $2016^{1}$

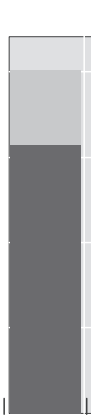

Co

Semiannual dealers

Triennial dealers
Gross market valuse ${ }^{2}$

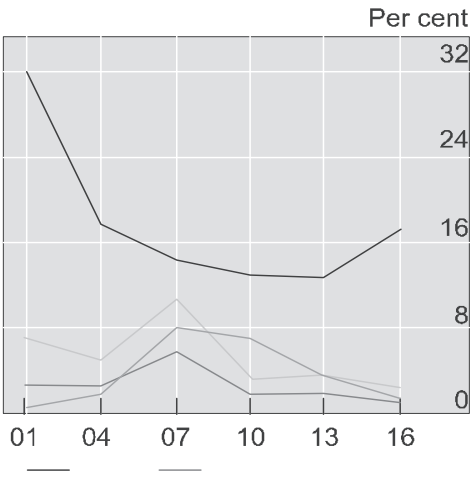

$C D$ - credit derivatives: $C o$ - Commodity derivatives: $E Q=$ equity-linked derivatives: $F X$ - foreign exchange derivatives: $\mid R=$ single-currency interest rate derivatives, $\mathrm{OD}=$ other OTC derivatives.

As a percentage of notional amounts outstanding at end-June 2016. Semiannual dealers refer to reporting dealers who participate in the semiannual survey, and Triennial dealers refer to those who participate only I the Triennial Survey, ie excluding semiannual dealers. For a list of countries whose dealers participate in this semiannual and Triennial surveys, see Annex C. : As a percentage of the gross market value of all outstanding OTC derivatives.

Source: BIS Triennial Central Bank Survey. Further information is available at www.bis.org/publ/rpfx16.htm.

\section{Most interest rate derivatives are centrally cleared}

For the first time, the latest semiannual and triennial surveys captured comprehensive data on positionswith CCPs. Whereas in previous surveys details about financial counterparties were collected only forCDS, at end-June 2016 CCPs were separately identified for all types of OTC derivatives. Central clearing isa key element in authorities' agenda for reforming OTC derivatives markets to reduce systemic risks. These new data show that central clearing has made very significant inroads into OTC interest ratederivatives markets but is much less prevalent in other OTC derivatives segments. The share of reporting dealers' positions booked against CCPs is highest for interest ratederivatives, where it stood at $75 \%$ at end-June 2016 . It is important to note that this share refers to theoutstanding positions of reporting dealers and not the share of trades cleared through CCPs; as a shareof outstanding positions, contracts with CCPs are counted twice, whereas as a share of trades eachcontract would be counted once. 


\section{Significance of central clearing}

Types of counterparties, as a percentage of national amounts outstanding at end-June 2016

Graph 2

OTC derivatives, By underlying risk and instrument

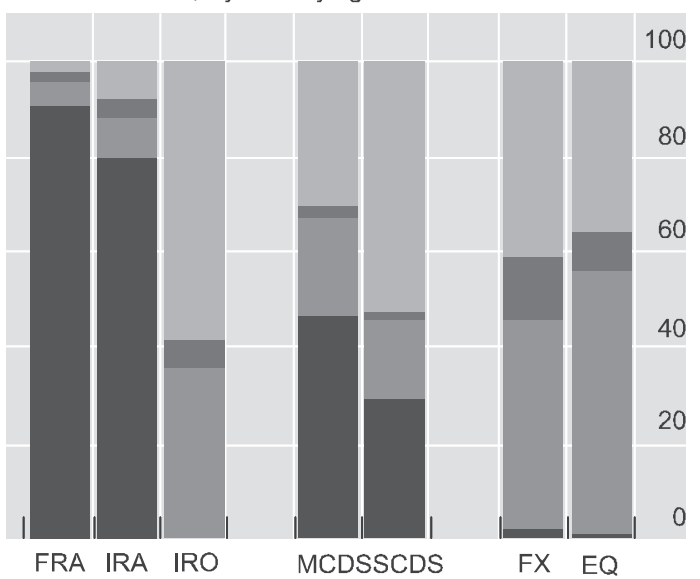

Interest rate derivatives

Credit derivatives Other derivatives
Interest rate swaps, by currency

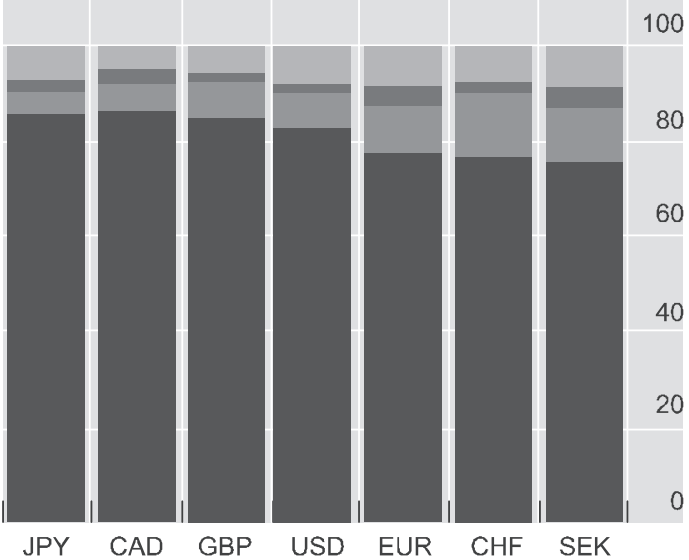

Central counterparties 1

Non-financial customers

Other financial institutionas2

Reporting dealers

$F R A=$ forward rate agreement: $F X=$ foreign exchange derivatives: IRS = interest rate swaps: IRO = interest rate options: $E Q=$ equity-linked derivative: $M C D S$ = multi-name credit default swaps: SCDS = single-name credit default swaps.

${ }^{1}$ Contracts between reporting dealers that are subsequently novated CCPs are recorded twice (reported once by each dealer). See footnote 4 on page 6 of the main text. ${ }^{2}$ excluding central counter parties and reporting dealers.

Source: BIS Triennial Central Bank Survey. Further information is available at www.bis,org/publ/rpfx16. htm.

Among interest-rate instruments, the share of positions booked against CCPs is highest for forward rate agreements and interest rate swaps, at $91 \%$ and $80 \%$, respectively (Graph 2 , lefthandpanel). For interest rate options, the share of CCPs is close to zero. The importance of CCPs does not varya lot across major currencies, ranging from $76 \%$ for interest rate swaps denominated in Swedish krona to $86 \%$ for those in Canadian dollars and Japanese yen, with US dollars in between at 83\% (Graph 2, right hand panel).

While comprehensive data on central clearing are available only from end-June 2016 , the share of positions with other financial institutions - from the historical counterparty distribution of OTC derivatives - can be used to approximate the pace of the shift in activity towards CCPs in recent years. Previously, CCPs were grouped indistinguishably with all financial institutions other than dealers, and the latest data show that CCPs accounted for most of the positions reported with this group of counterparties.

The share of interest rate derivatives with financial institutions other than dealers climbed from $61 \%$ of notional amounts outstanding at end-June 2010 to $75 \%$ at end-June 2013 and $86 \%$ at end-June 2016 . In contrast, the interdealer segment declined in importance, from $30 \%$ to $12 \%$ over this period. These opposing trends likely reflect the novation of inter-dealer contracts to CCPs. The notional principal of interest rate contracts between derivatives dealers has been falling more or less steadily since the Great Financial Crisis, dropping from $\$ 163$ trillion at end-June 2007 to $\$ 50$ trillion at end-June2016. Central clearing is also gaining in importance in credit derivatives markets. 
The proportion of outstanding credit default swaps (CDS) cleared through CCPs has increased steadily since these datawere first reported in 2010, from $10 \%$ at end-June 2010 to $23 \%$ at end-June 2013 and $37 \%$ at end-June 2016. The share of CCPs is higher for multi-name products than for single-name products: $47 \%$ versus $29 \%$ (Graph 2, left-hand panel). Multi-name products, which consist primarily of contracts on CDSindices, tend to be more standardized than single-name products and consequently more amenable to central clearing. As CDS become more standardized, CCPs' share of newer contracts is likely to increase. Nevertheless, CDS with remaining maturity of one year or less have a lower share of central clearing $(27 \%)$ than those maturing in one to five years (41\%).

In contrast, dealers from advanced economies are active in a wider range of markets. For many major dealers, contracts denominated in their domestic currency accounted for less than 50\% of theiroutstanding interest rate derivatives, with contracts in US dollars or euros accounting for much of theremainder (Graph 4, left-hand panel). Similarly, many manage FX risks not linked to their domestic currency. For a few dealers from advanced economies, FX contracts involving their domestic currency onone side accounted for less than $30 \%$ of the outstanding notional positions (Graph 4, right-hand panel).

\section{Risk Composition of outstanding positions, by nationality of dealer}

As a percentage of all OTC derivatives outstanding at end-June 2016

Graph 3

National amounts of interest rate and FX derivatives ${ }^{1}$ Gross market values, by region where dealer is based

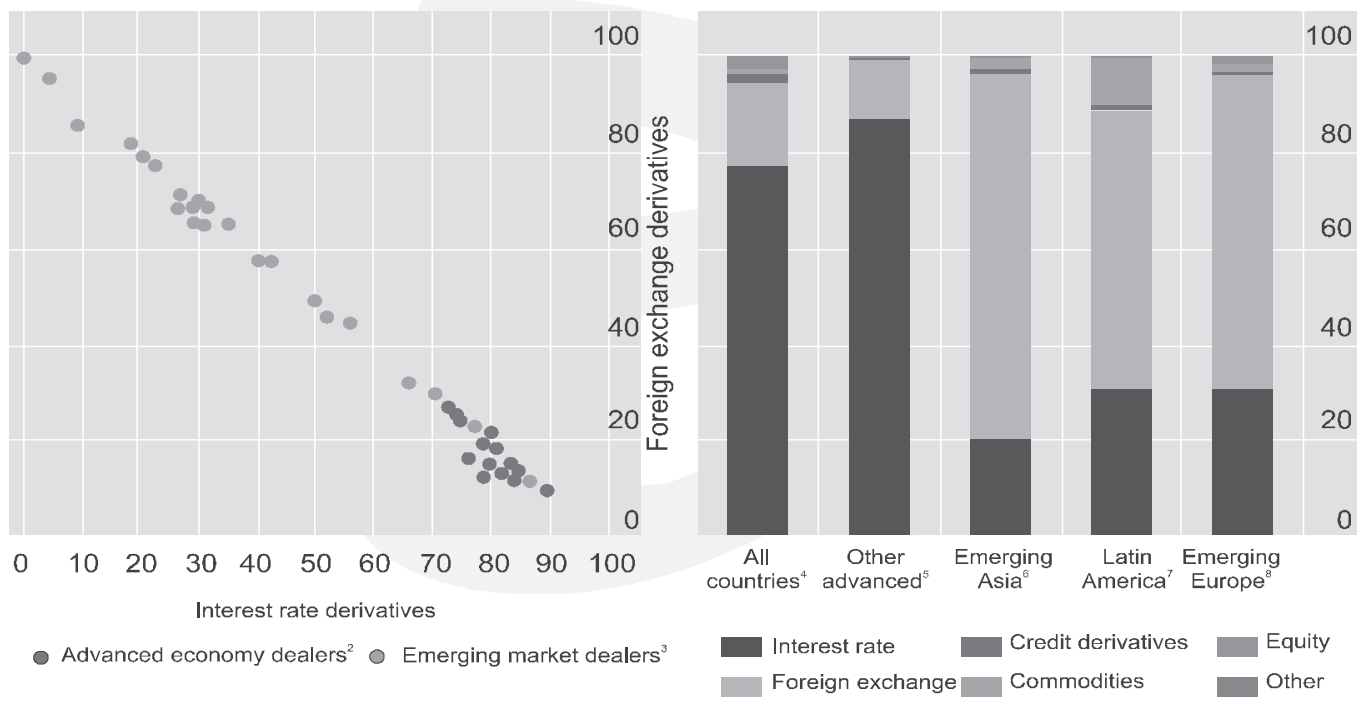

\footnotetext{
Dots show the risk composition of national amount reported by dealers headquartered in each country participating in the semiannual and triennial surveys. For a list of participating countries, see Annex C. Dealers report their worldwide consolidated positions. ${ }^{2}$ Dealers from AU, AT, BE, CA, CH, De, DK, ES, FI, FR, GB, GR, IE, IT, JP, NL, No, PT, SE and US. ${ }^{3}$ Dealers from countries that participate in the Triennial Survey, excluding those listed in footnote 2. See Annex C. ${ }^{4}$ All countries that participate in the semiannual and triennial surveys. ${ }^{5} \mathrm{AT}, \mathrm{DK}, \mathrm{FI}, \mathrm{GR}, \mathrm{IE}, \mathrm{No}, \mathrm{PT}$. Excludes dealers from the 13 countries that participate in the semiannual survey. ${ }^{6} \mathrm{CN}, \mathrm{HK}, \mathrm{ID}, \mathrm{IN}$, $\mathrm{KR}, \mathrm{MY}, \mathrm{PH}, \mathrm{SG}, \mathrm{TH}, \mathrm{TW} .{ }^{7} \mathrm{AR} \mathrm{BR}, \mathrm{CL}, \mathrm{CO}, \mathrm{Mx}, \mathrm{Pe} .{ }^{8} \mathrm{HU}, \mathrm{LV}, \mathrm{PL}, \mathrm{RO}, \mathrm{Ru}$, and Tr, plus the Middle East (BH, IL, SA) and Africa (ZA).
}

Sources: BIS Triennial Central Bank Survey. Further information is available at www.bis.org/publ/rpfx16.htm. 
Table: Global OTC derivatives markets

Amounts outstanding, in billions of US dollars ${ }^{2}$

\begin{tabular}{|c|c|c|c|c|c|c|}
\hline & \multicolumn{3}{|c|}{ National amounts outstanding } & \multicolumn{3}{|c|}{ Gross market value } \\
\hline & $\begin{array}{c}\text { end-June } \\
2010\end{array}$ & $\begin{array}{c}\text { end-June } \\
2013\end{array}$ & $\begin{array}{c}\text { end-June } \\
2016\end{array}$ & $\begin{array}{c}\text { end-June } \\
2010\end{array}$ & $\begin{array}{c}\text { end-June } \\
2013\end{array}$ & $\begin{array}{c}\text { end-June } \\
2016\end{array}$ \\
\hline GRAND TOTAL & 582,683 & 696,120 & 544,052 & 24,695 & 20,234 & 20,701 \\
\hline A. Foreign exchange contracts & 62,961 & 80,917 & 85,170 & 3,179 & 2,613 & 3,558 \\
\hline Forwards and swaps & 31,934 & 39,495 & 46,889 & 1,335 & 1,082 & 1,698 \\
\hline Currency swaps & 18,903 & 26,292 & 25,855 & 1,386 & 1,169 & 1,550 \\
\hline Options & 12,123 & 15,074 & 12,907 & 458 & 362 & 310 \\
\hline Other & 1 & 56 & 60 & $\cdots$ & $\cdots$ & $\cdots$ \\
\hline B. Interest rate contracts 2 & 478,093 & 580,599 & 437,739 & 18,508 & 15,763 & 16,005 \\
\hline Forward rate agreements & 60,028 & 89,992 & 74,727 & 204 & 276 & 381 \\
\hline Interest rate swaps & 367,541 & 439,838 & 327,445 & 16,703 & 14,135 & 14,226 \\
\hline Options & 50,519 & 50,191 & 35,427 & 1,600 & 1,352 & 1,397 \\
\hline Other & 5 & 579 & 140 & $\cdots$ & $\ldots$ & $\cdots$ \\
\hline C. Equity-linked contracts & 6,868 & 6,963 & 6,761 & 796 & 706 & 522 \\
\hline Forwards and swaps & 1,854 & 2,350 & 2,592 & 202 & 209 & 175 \\
\hline Options & 5,013 & 4,614 & 4,169 & 595 & 498 & 347 \\
\hline D. Commodity contracts 3 & 3,273 & 2,717 & 1,761 & 493 & 391 & 260 \\
\hline Gold & 669 & 610 & 500 & 54 & 83 & 47 \\
\hline Other & 2,604 & 2,108 & 1,261 & 439 & 309 & 212 \\
\hline Forwards and swaps & 1,686 & 1,394 & 936 & $\ldots$ & $\ldots$ & $\ldots$ \\
\hline Options & 918 & 714 & 325 & $\cdots$ & $\cdots$ & $\cdots$ \\
\hline E. Credit derivatives & 31,416 & 24,845 & 11,991 & 1,708 & 732 & 351 \\
\hline Forwards and swaps & 31,331 & 24,497 & 11,881 & $\ldots$ & $\ldots$ & $\ldots$ \\
\hline CDS & 31,057 & 24,469 & 11,861 & 1,694 & 728 & 346 \\
\hline Single-name instruments & 18,920 & 13,211 & 6,681 & 1,012 & 432 & 219 \\
\hline Multi-name instruments & 12,136 & 11,258 & 5,180 & 681 & 296 & 127 \\
\hline Index products & 7,500 & 10,163 & 4,836 & $\cdots$ & $\cdots$ & $\ldots$ \\
\hline Options & 85 & 348 & 110 & $\ldots$ & $\cdots$ & $\cdots$ \\
\hline F. Other derivatives & 72 & 78 & 89 & 12 & 29 & 6 \\
\hline Forwards and swaps & 38 & 63 & 75 & $\cdots$ & $\ldots$ & $\cdots$ \\
\hline Options & 34 & 15 & 14 & $\ldots$ & $\ldots$ & $\ldots$ \\
\hline GROSS CREDIT EXPOSURE ${ }^{4}$ & $\cdots$ & $\ldots$ & $\ldots$ & 3,581 & 3,784 & 3,692 \\
\hline Memo: Exchange-traded contracts ${ }^{5}$ & 69,898 & 62,503 & 67,700 & $\cdots$ & $\cdots$ & $\ldots$ \\
\hline
\end{tabular}

All figures are adjusted for double-counting of trades between dealers. Notional amounts outstanding have been adjusted by halving positions vis-à-vis other reporting dealers. Gross market values have been calculated as the sum of the total gross positive market value of contracts and the absolute value of the gross negative market value of contracts with nonreporting counterparties. 2 Single currency contracts only. 3 Adjustments for doublecounting partly estimated.

Gross market values after taking into account legally enforceable bilateral netting agreements. 5 Open interest of foreign exchange and interest rate futures and options traded worldwide. Sources: Euromoney TRADEDATA, Futures Industry Association; The Options Clearing Corporation; BIS derivatives statistics. 
Authorities from an additional 33 countries participated in the outstanding position part of the latest Triennial Central Bank Survey of FX and OTC Derivatives markets.

\begin{tabular}{llll}
\hline Country & Reporting authority & Country & Reporting authority \\
\hline Argentina & Central Bank of Argentina & Israel & Bank of Israel \\
Austria & $\begin{array}{l}\text { Central Bank of the Republic of } \\
\text { Austria }\end{array}$ & Korea & Bank of Korea \\
Bahrain & Bahrain Monetary Agency & Malaysia & Central Bank of Malaysia \\
Brazil & Central Bank of Brazil & Mexico & Bank of Mexico \\
Chile & Central Bank of Chile & Norway & Central Bank of Norway \\
China & People's Bank of China & Peru & Central Reserve Bank of Peru \\
& State Administration of Foreign & Philippines & Bangko Sentral ng Pilipinas \\
& Exchange & Poland & Narodowy Bank Polski \\
$\begin{array}{l}\text { Chinese Taipei } \\
\text { Colombia }\end{array}$ & Central Bank of China & Portugal & Bank of Portugal \\
Denmark & Bank of the Repubilc & Romania & National Bank of Romania \\
$\begin{array}{l}\text { Finland } \\
\text { Greece }\end{array}$ & Denmarks National Bank & Russia & Central Bank of the Russian \\
Hong Kong SAR & Bank of Finland & & Federation \\
Hungary & Bong Kong Monetary Authority & Singapore & Monetary Authority of Singapore \\
India & Magyar Nemzeti Bank & South Africa & South African Reserve Bank \\
Indonesia & Reserve Bank of India & Thailand & Bank of Thailand \\
Ireland & Bank Indonesia & Turkey & Central Bank of the Republic \\
\hline
\end{tabular}

\section{OTC derivatives statistics at end-June 2016}

Bulgaria participated in the outstanding positions part of the Triennial Survey from 2007 to

2013. Australia and Spain participated only in the Triennial Survey through 2010 and from end2011 participated in the semiannual survey too. An additional six countries participated in the turnover part ofthe latest Triennial Central Bank Survey. The market share of dealers that participate in the semiannual survey varies across riskcategories. It is highest in the credit, equity and interest rate segments $(99 \%, 98 \%$ and $96 \%$, respectively, at end-June 2016) and lowest in the commodity and foreign exchange segments (79\% and $86 \%$ ). Overall,the results of the Triennial Survey indicate that the semiannual survey captured about $94 \%$ of global OTC derivatives positions at end-June 2016. The next Triennial Survey of outstanding positions will be conducted in June 2019.

\section{Section IV}

\section{Summary and Concluding Remarks}

Innovation of derivatives have redefined and revolutionized the landscape of financial industry across the world and derivatives have earned a well deserved and extremely significant place among all the financial products. Derivatives are risk management tool that help in effective management of risk by various stakeholders. Derivatives provide an opportunity to transfer risk, from the one who wish to avoid it; to one, who wish to accept it. India's experience with the launch of equity derivatives market has been extremely encouraging and successful. The derivatives turnover on the NSE has surpassed the equity market turnover. Significantly, its growth in the recent years has surpassed the growth of its counterpart globally. 
The turnover of derivatives on the NSE increased from Rs. 23,654 million (US \$ 207 million) in 2000-01 to Rs. $130,904,779$ million (US \$ $3,275,076$ million) in 2007-08. India is one of the most successful developing countries in terms of a vibrant market for exchange-traded derivatives. This reiterates the strengths of the modern development of India's securities markets, which are based on nationwide market access, anonymous safe and secure electronic trading, and a predominantly retail market. There is an increasing sense that the equity derivatives market is playing a major role in shaping price discovery. Factors like increased volatility in financial asset prices; growing integration of national financial markets with international markets; development of more sophisticated risk management tools; wider choices of risk management strategies to economic agents and innovations infinancial engineering, have been driving the growth of financial derivatives worldwide and have also fuelled the growth of derivatives here, in India. There is no better way to highlight the significance and contribution of derivatives but the comments of the longest serving Governor of Federal Reserve, AlanGreenspan: "Although the benefits and costs of derivatives remain the subject of spirited debate, the performance of the economy and the financial system in recent years suggests that those benefits have materially exceeded the costs.

\section{References}

'Trading statistics of Derivatives segment at BSE', available at: www. bseindia.com.

Bodla, B. S. and Jindal, K. (2008), 'Equity Derivatives in India: Growth Pattern and Trading Volume Effects', The ICFAI Journal of Derivatives Markets, Vol. V. No. 1, pp.62-82.

Growth of Derivatives Market in India, available at: http://www.valuenotes.com/njain/ nj_derivatives_15sep03.asp?ArtCd=33178\&Cat $=\mathrm{T} \& \mathrm{ld}=10$

Harish, A. S. (2001) 'Potential of Derivatives Market in India', The ICFAI Journal of Applied Finance, Vol. 7, No.5, pp 1-24.
Hirani, Kapil (2007), 'Understanding Derivatives', available at:http://kapilhirani.com/ News5.php http://www.indiainfoline.com/news/ showleader.asp? Imn =1\&storyld =344

ht t p: // ww w. valuenotes.com/njain/ nj derivatives 15sep03.asp?ArtCd $=33178 \&$ Cat $=$ T\&ld $=10$

'Indian Securities Market, A Review' (ISMR)2008 available at:http://www.nseindia.com.

'International Options Market Association (IOMA) Derivatives Market Survey' 2007, availableat: http://www.world-exchanges.org/ioma (accessed on May 30, 2009).

'Introduction to derivatives in India', available at: http://business.mapsofindia.com/ investmentindustry/introduction-toderivatives.html.

Kannan, R. (2008), 'Onset of Derivatives Trading in Derivatives market', available at:www.geocities.com/kstability/content/ derivatives/first.html

Kaur, P.(2004), 'Financial derivatives: Potential of derivative market in India and emerging derivatives market structure in India' available at: www.icwai.org/icwai/knowledgebank

MisraDheeraj and MisraSangeeta D (2005), 'Growth of Derivatives in the Indian Stock Market: Hedging v/s Speculation', The Indian Journal of Economics, Vol. LXXXV, No. 340.

NSE fact book, 2008 Issue, available at: http:// www.nseindia.com.

Reddy, Y. V. and Sebastin, A. (2008), 'Interaction between Equity and Derivatives Markets in India: An Entropy Approach', The ICFAI Journal of Derivatives Markets, Vol. V, No.1, pp.18-32.

Sarkar, A. (2006), 'Indian Derivatives Markets' available at:

www. newyorkfed.org/research/economists/ sarkar/derivatives in india.pdf

Srivastava, P. (2004), 'Financial and legal aspect of derivative trading in.India', available at: www.taxmann.net/Datafolder/Flash/ article0412_4.pdf (accessed on May 10,2009). 